\title{
IMPLEMENTASI E-COMMERCE MENGGUNAKAN CONTENT MANAGEMENT SYSTEM (CMS) UNTUK MEMPERLUAS PEMASARAN PADA INDAH JAYA SPORT
}

\author{
Agy Nugroho', Hendri Irawan ${ }^{2}$ \\ ${ }^{1,2}$ Fakultas Teknologi Informasi, Sistem Informasi , Universitas Budi Luhur, Jakarta, Indonesia \\ Email: *1agy.nugroho@gmail.com, ${ }^{2}$ hendri.irawan@budiluhur.ac.id
}

\begin{abstract}
Abstrak-Dengan semakin majunya teknologi, membuat jaman berubah dan sangat mudah untuk menyampaikan informasi, hingga kondisi pasar saat ini sudah mulai beralih memanfaatkan teknologi untuk sarana penyampaian informasi. Namun sangat disayangkan toko Indah Jaya Sport masih belum menggunakan teknologi untuk fasilitas penyampaian data serta promosi, Indah Jaya Sport adalah toko yang menjadi salah satu sarana untuk membeli alat olahraga untuk para pelanggan seperti olahragawan, atlet atau pelanggan yang memerlukan alat untuk berolahraga. Karena Indah Jaya Sport belum memanfaatkan teknologi, hal itu menyebabkan kurang luasnya jangkauan pasar pada toko Indah Jaya Sport dan mengakibatkan calon pelanggan kekurangan informasi tentang toko Indah Jaya Sport. Dalam penelitian ini metode business model canvas adalah metode yang tepat untuk menganalisis model pengembangan bisnis yang ada pada toko Indah Jaya Sport dan implementasi $e$-commerce menggunakan content management system (CMS) serta menyiapkan strategi search engine optimization dan pemasaran agar dapat memperluas jangkauan pemasaran dan memberi kemudahan dalam mengakses informasi untuk calon pelanggan pada toko Indah Jaya Sport. Kesimpulan dari penelitian ini yaitu dengan adanya website e-commerce, toko Indah Jaya Sport memiliki sarana untuk melakukan promosi dan sarana penyampaian informasi dengan menggunakan fitur Search Engine Optimization dan fitur-fitur lainnya yang terdapat pada website e-commerce.
\end{abstract}

Kata Kunci: Teknologi, Pemasaran, Search Engine Optimization, E-Commece, Indah Jaya Sport

\begin{abstract}
With the advancement of technology, times have changed and it is very easy to convey information, so that the current market conditions have begun to switch to using technology as a means of conveying information. However, it is very unfortunate that the Indah Jaya Sport shop still does not use technology for data delivery and promotion facilities, Indah Jaya Sport is a shop that is one of the means to buy sports equipment for customers such as sportsmen, athletes or customers who need equipment for exercising. Because Indah Jaya Sport has not yet utilized technology, this has resulted in a lack of market reach at the Indah Jaya Sport store and resulted in prospective customers lacking information about the Indah Jaya Sport store. In this study, researchers used the business model canvas method to analyze existing business development models at Indah Jaya Sport stores and implement e-commerce using a content management system (CMS) and prepare search engine optimization and marketing strategies in order to expand marketing reach and provide convenience. in accessing information for potential customers at the Indah Jaya Sport store. The conclusion of this research is that with the existence of an e-commerce website, the Indah Jaya Sport store has the means to carry out promotions and the means of conveying information using the Search Engine Optimization feature and other features found on the e-commerce website.
\end{abstract}

Keywords: Technology, Marketing, Search Engine Optimization, E-Commerce, Indah Jaya Sport

\section{PENDAhuluan}

Pada saat ini, teknologi informasi semakin maju dari tahun ke tahun dan semakin berkembang pesat serta dapat memberikan kemudahan bagi masyarkat dalam melakukan berbagai macam kegiatan. Salah satu kemajuan teknologi yang memberikan dampak yang cukup besar untuk kehidupan bermasyarakat yaitu internet, dengan internet manusia dapat melakukan berbagai macam kegiatan mulai dari bertukar informasi sampai dengan berbisnis. Adanya teknologi internet yang semakin memudahkan kegiatan berbisnis memunculkan peluang baru yang bisa dimanfaatkan oleh para masyarakat khususnya pelaku usaha. Ketatnya persaingan bisnis saat ini membuat para pelaku usaha harus ikut memanfaatkan teknologi internet dalam bertukar informasi untuk menjual produknya secara online dengan memanfaatkan sebuah sistem penjualan secara online dengan konsep e-commerce untuk menjangkau pasar yang lebih besar dan meningkatkan penjualan secara optimal.

E-commerce adalah metode jual beli yang terjadi di Internet di mana berbagai barang atau jasa dapat dijual melalui komputer atau perangkat yang terhubung ke Internet. [1]. E-commerce adalah pilihan bisnis yang sangat efektif untuk memperluas jangkauan penjualan dan ini dapat memberikan kenyamanan besar bagi penjual dan pelanggan dalam perdagangan dan jual beli. Banyaknya manfaat pada $e$-commerce membuat para pelaku usaha ingin memanfaatkan serta menerapkan sistem e-commerce ini pada toko ataupun perusahaannya untuk mempermudah dalam melakukan transaksi dan meningkatkan penjualan produk.

Toko Indah Jaya Sport hadir untuk melengkapi keperluan masyarakat khususnya dalam berolahraga, Indah Jaya Sport adalah toko yang menjual perlengkapan olahraga yang berdomisili di Pasar Bengkok, Tangerang, Banten. Toko Indah Jaya Sport memiliki permasalahan dimana pemilik toko tidak mempunyai media yang bisa di manfaatkan untuk melakukan promosi, hal itu menyebabkan kuang luasnya jangkauan pasar pada Indah Jaya Sport 
dan berdampak pada calon pelanggan kekurangan informasi tentang toko Indah Jaya Sport serta pemilik toko belum mengetahui cara meningkatkan penjualan produk di karenakan hanya berjualan secara konvensional saja, yang menyebabkan penjualan menjadi kurang efektif, dan berdampak pada kurang banyaknya transaksi yang di dapat, dan serta beberapa masalah lain pada toko Indah Jaya Sport. Oleh karena itu Indah Jaya Sport memerlukan sistem informasi penjualan dengan konsep e-commerce untuk memecahkan permasalahan tersebut.

Tujuan dari penelitian ini adalah untuk merancang dan membangun sistem penjualan online dengan menggunakan konsep e-commerce berbasis web, diharapkan menjadi solusi agar toko Indah Jaya Sport dapat memeperluas kawasan pemasaran agar masyarakat atau calon pelanggan dapat mengetahui tentang toko Indah Jaya Sport. Beberapa studi literatur yang terkait dengan penelitian yang sedang dilakukan, yaitu: penelitian pertama [2] yang membahas penerapan e-commerce dengan jenis business to customer pada industri garment. Penelitian kedua [3] yang membahas tentang pengaruh SEO untuk toko online. Penelitian ketiga [4] yang membahas tentang implementasi penjualan menggunakan e-commerce pada Synergie Motor. Penelitian keempat [5] yang membahas tentang implementasi e-commerce dengan metode business model canvas di distro Mr.Bro. Penelitian kelima [6] membahas tentang implementasi e-commerce sebagai sarana jual-beli online di toko Tatashops. Berdasarkan sistem berjalan saat ini dan studi literatur di atas maka peneliti melakukan penelitian untuk membuat sistem $e$ commerce sesuai dengan kebutuhan toko Indah Jaya Sport. Perbedaaan pada penelitian sebelumnya yaitu peneliti membuat penelitian ini untuk memperluas pemasaran pada toko Indah Jaya Sport dengan menggunakan fitur search engine optimization (SEO) dan retur produk agar website e-commerce toko Indah Jaya Sport semakin luas dan dipercaya oleh pelanggan. Manfaat dari penelitian ini adalah untuk mempermudah toko Indah Jaya Sport memasarkan produk melalui internet dan memperluas jangkauan penjualan.

\section{METODE PENELITIAN}

Metode penelitian adalah langkah penelitian yang diambil oleh teknik inisiasi yang mendefinisikan metodologi tersebut. dan digunakan untuk memecahkan masalah penelitian. Metode penelitian yang dilakukan peneliti dapat dilihat pada Gambar 1 :

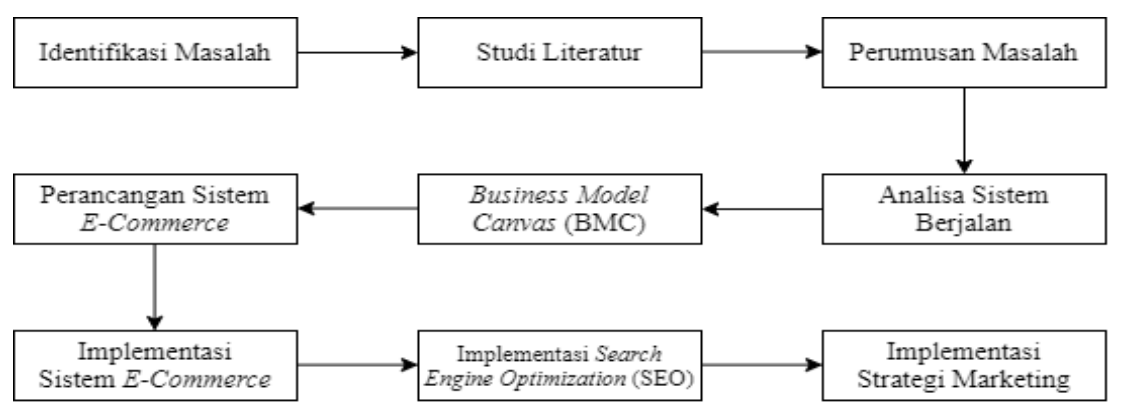

Gambar 1. Metode Penelitian

Berdasarkan Gambar 1 penjelasan alur yang dilakukan yaitu diawali dengan identifikasi masalah dengan menggunakan metode wawancara dan observasi dan hasil yang didapat dari metode tersebut penulis mendapatkan kesimpulan dari beberapa masalah yang ada untuk di jadikan perumusan masalah yang dapat dipecahkan dengan menggunakan sistem e-commerce, lalu menggunakan studi literatur untuk hasil yang didapat dari studi literatur tersebut yaitu penulis mendapatkan beberapa permasalahan baru yang terdapat pada Indah Jaya Sport dan berbeda dari identifikasi masalah yang telah dilakukan dengan wancara dan observasi, setelah itu melakukan perumusan masalah dengan beberapa masalah yang ada dan penulis mendapatkan akar masalah yang terdapat pada toko Indah Jaya Sport dan merumuskan masalah dengan sebab dan akibat yang ada pada toko Indah Jaya Sport, peneliti kemudian menggunakan activity diagram untuk menganalisis sistem yang sedang berjalan. dan hasil yang di dapatkan oleh peneliti yaitu mengetahui sistem berjalan secara rinci serta menjadi rujukan key activities pada business model canvas pada toko Indah Jaya Sport, setelah itu untuk melakukan analisis pengembangan bisnis peneliti menggunakan business model canvas dan hasil yang didapat oleh peneliti dengan menggunakan metode business model canvas adalah jelasnya target penjualan, pengeluaran yang akan dikeluarkan, media pemasaran, dan hal lainnya, setelah itu peneliti melakukan perancangan sistem e-commerce untuk toko Indah Jaya Sport menggunakan use case diagram dan rancangan layar menggunakan tools adobe xd dan draw.io untuk hasil yang lebih optimal saat implementasi, lalu peneliti melakukan implementasi sistem e-commerce menggunakan dua tahapan yaitu eksplorasi dan implementasi dengan content management system di worpdress. Wordpress adalah wadah jaringan online untuk keperluan tulis-menulis secara kompleks [7], lalu peneliti melakukan testing terlebih dahulu di localhost agar sistem lebih baik dan terhindar dari bug atau gagalnya pengoprasian saat di implementasi, 
kemudian menggunakan hosting dan domain untuk tahap akhir implementasi e-commerce, setelah itu peneliti melakukan implementasi search engine optimization dan hasil yang didapat dari implementasi search engine optimization adalah sistem e-commerce yang akan di terapkan pada toko Indah Jaya Sport akan lebih dikenal luas oleh masyarakat, dan yang terkahir peneliti melakukan implementasi strategi marketing menggunakan media sosial facebook dan Instagram dan hasilnya para pelanggan dapat mengetahui informasi terbaru pada toko Indah Jaya Sport dan diharapkan dapat memperbanyak transaksi penjualan pada toko Indah Jaya Sport.

\section{HASIL DAN PEMBAHASAN}

\subsection{Business Model Canvas}

Business Model Canvas adalah metode yang digunakan untuk mengelola dan mengatur strategi bisnis yang dibuat secara visual untuk membantu pengguna memahami pengembangan bisnis [1]. Business model canvas toko Indah jaya Sport dapat dilihat pada Gambar 2 :

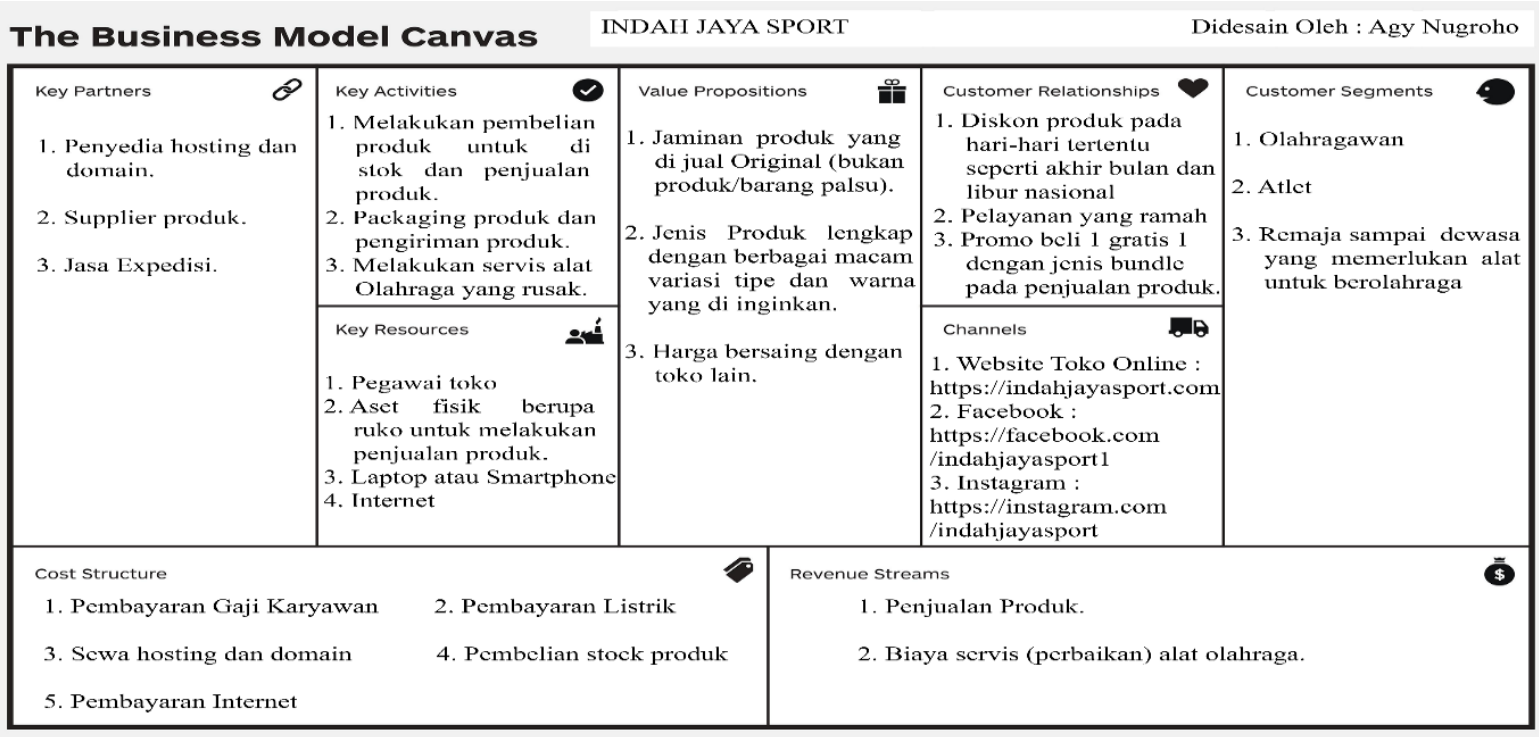

Gambar 2. Business Model Canvas Indah Jaya Sport

Komponen-komponen business model canvas beserta deskripsinya yang telah di analisis pada toko Indah Jaya Sport :

a. Value Propotition adalah nilai yang ditawarkan oleh toko Indah Jaya Sport kepada pelanggan yaitu berupa jaminan produk yang dijual original, jenis produk yang lengkap dengan berbagai macam variasi tipe dan warna yang di inginkan.

b. Customer Segment adalah target pasar yang dituju oleh toko Indah Jaya Sport sangat spesifik yaitu mulai dari olahragawan, atlet, dan remaja sampai dewasa yang membutuhkan peralatan olahraga.

c. Channel adalah sarana untuk mendistribusikan atau mempromosikan produk pada toko Indah Jaya Sport dengan menggunakan website toko online Indah Jaya Sport (https://indahjayasport.com), dan media sosial berupa facebook (https://facebook.com/indahjayasport1) dan Instagram (https://instagram.com/indahjayasport).

d. Customer Relatonships adalah menjaga hubungan antar melanggan agar pelanggan datang Kembali ke toko Indah Jaya Sport dengan mengadakan diskon produk dihari tertentu, melayanai pelanggan dengan ramah, dan mengadakan promo dengan beli 1 gratis 1 dengan bundle penjualan.

e. Revenue Stream adalah pendapatan yang didapat oleh toko Indah Jaya Sport dengan cara menjual produk dan biaya perbaikan peralatan olahraga yang rusak.

f. Key Activities adalah semua kegiatan atau aktivitas utama yang dilakukan toko Indah Jaya Sport agar memberikan nilai atau manfaat dapat tecapai aktivitas tersebut yaitu melakukan penjualan dan pembelian stok produk, packaging produk lalu mengirim produk, dan melakukan perbaikan alat olahraga yang rusak.

g. Key Resource merupakan hal penting yang harus dimiliki Indah Jaya Sport agar key activities dapat berjalan dan value proposition dapat diberikan untuk pelanggan, key resource pada toko Indah Jaya Sport berupa 
sumberdaya manusia (pegawai), aset fisik untuk melakukan penjualan produk, laptop atau smartphone, dan internet.

h. Key Partners yaitu adalah entitas-entitas yang mendukung usaha tersebut yang dibutuhkan oleh toko Indah Jaya Sport, hal ini berguna agar toko Indah Jaya Sport bisa fokus pada kegiatan utama yang dilakukan, untuk itu toko Indah jaya Sport berkerja sama kepada penyedia hosting dan domain, supplier produk, dan jasa ekspedisi atau pengiriman.

i. Cost Structure merupakan keluaran biaya secara detail oleh toko Indah Jaya Sport untuk melakukan key activities. Berikut ini pengeluaran yang dikeluarkan toko Indah Jaya Sport setiap bulannya seperti pembayaran gaji karyawan, pembayaran listrik, sewa hosting dan domain, pembelian stok produk dan pembayaran internet.

\subsection{Proses Bisnis Usulan}

Activity diagram merupakan diagram yang menggambarkan alur kerja ataupun kegiatan pada sistem yang ada di fitur perangkat lunak [8].

a. Activity diagram proses pemesanan produk

Activity diagram proses pemesanan produk ini menjelaskan pelanggan mengunjungi halaman produk Indah Jaya Sport dan memilih produk, kemudian memilih opsi, jika sudah sesuai maka tambahkan ke keranjang. Jika pelanggan ingin berbelanja lagi maka pelanggan memilih produk lagi, jika pelanggan sudah tidak membeli produk maka pelanggan pergi ke halaman keranjang dan pelanggan melihat total harga barang yang ingin dibelanjakan, jika pelanggan mempunyai kupon maka pelangan masukkan kode kupon tersebut untuk mendapatkan diskon lalu men-checkout pesanan, jika tidak punya kupon maka pelanggan langsung checkout, setelah pelanggan melakukan checkout maka pelanggan mengisi data pengiriman. lalu pilih kurir yang di inginkan. Activity diagram proses pemesanan produk dapat dilihat pada Gambar 3 :

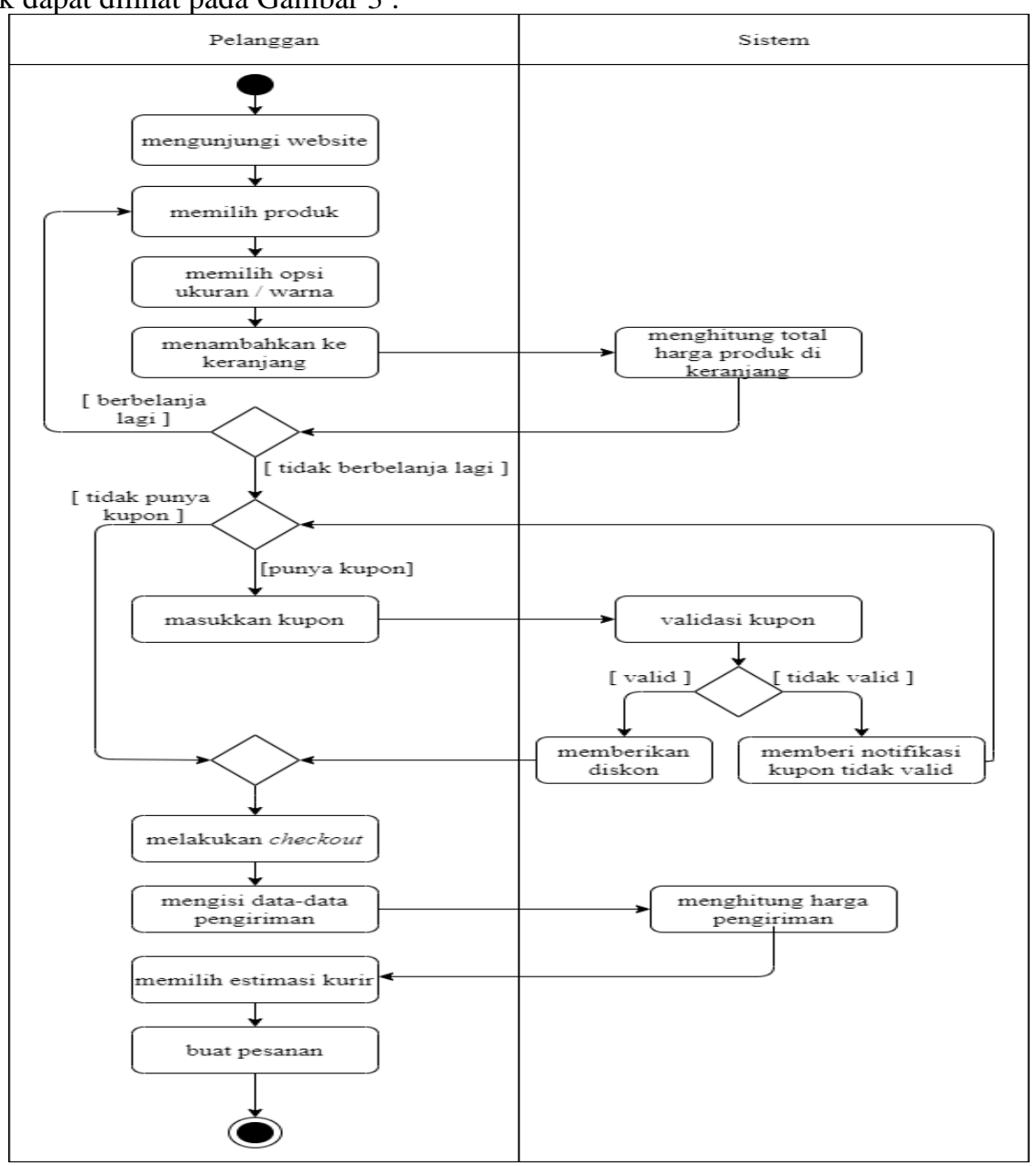

Gambar 3. Activity Diagram Proses Pemesanan Produk

b. Activity diagram proses pemabayaran produk 
Activity Diagram Proses Pembayaran Produk ini menjelaskan saat setelah pelanggan mengisi data-data untuk pengiriman, terdapat nomer rekening pemilik toko yang terlihat oleh pelanggan, kemudian pelanggan mentransfer sesuai total yang dipesan ke rekening pemilik toko Indah Jaya Sport, setelah itu pelanggan membuka halaman konfirmasi pembayaran lalu mengisi form konfirmasi pembayaran sesuai data-data yang diminta pada form konfirmasi pembayaran. Pelanggan yang telah mengirim bukti pembayaran akan masuk ke e-mail Indah Jaya Sport dan akan di validasi oleh pegawai toko Indah Jaya Sport, jika bukti pembayaran tidak valid maka pesanan tidak akan di proses, jika bukti pembayaran valid maka pegawai Indah Jaya Sport akan memproses pesanan produk sesuai dengan pesanan pelanggan. Activity diagram proses pembayaran produk dapat dilihat pada Gambar 4 :

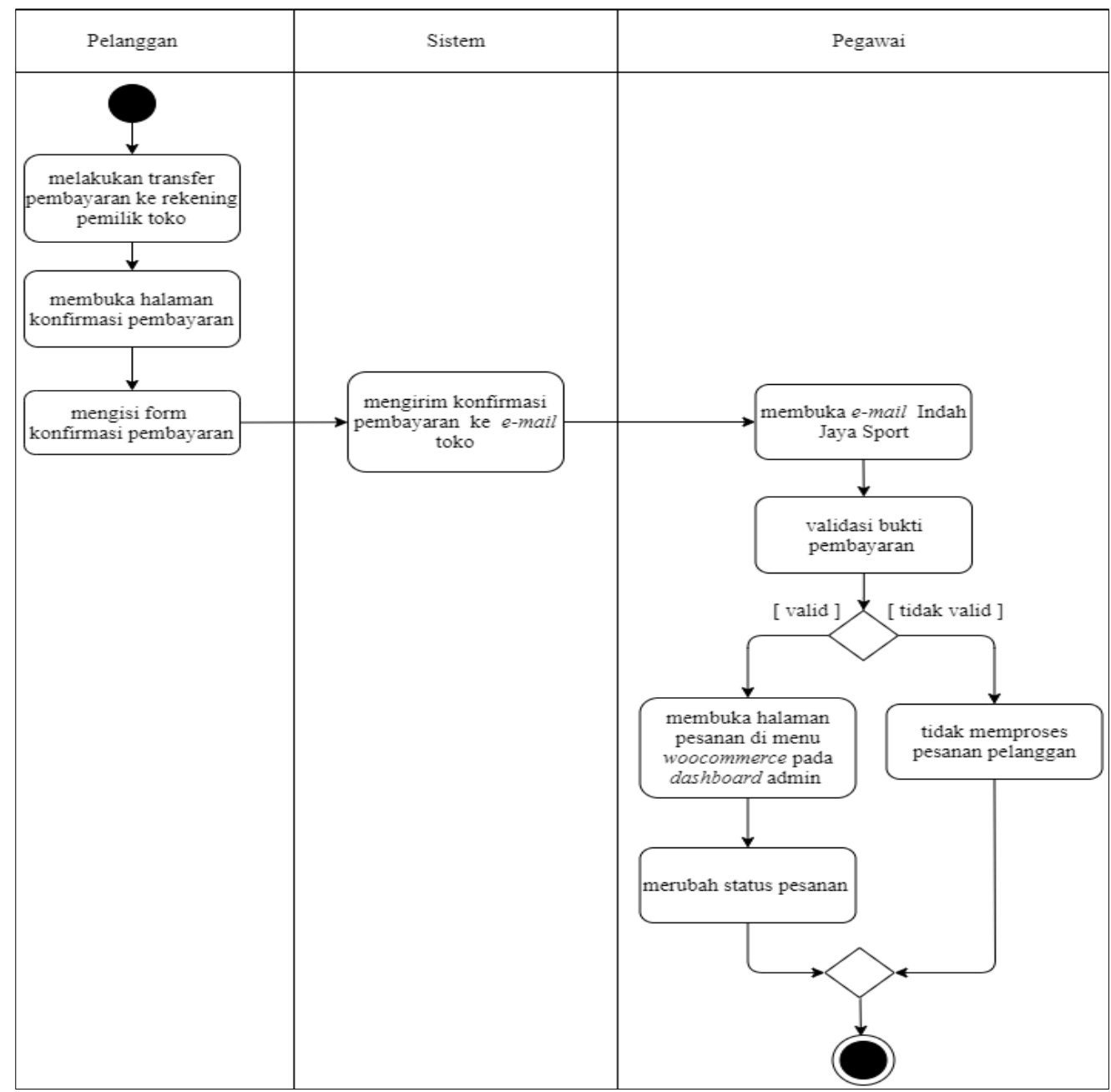

Gambar 4. Activity Diagram Proses Pembayaran Produk

\subsection{Use Case Diagram}

Use case bekerja dengan menjelaskan tipikal interaksi umum antar pengguna sistem dengan sistem nya sendiri melalui riwayat penggunaan sistem [8]. Use case diagram yang di implementasi pada website toko Indah Jaya Sport terdiri dari aktor pegawai, pemilik, pelanggan dan sistem yang akan melakukan interaksi untuk mengoperasikan website Indah Jaya Sport dan akan mencetak laporan-laporan terkait untuk pengambilan keputusan oleh pihak toko Indah Jaya Sport. Use case diagram pada website yang di implementasi toko Indah Jaya Sport dapat dilihat pada Gambar 5 : 
INDONESIA JOURNAL INFORMATION SYSTEM (IDEALIS)

Volume 4, Nomor 4, Juli 2021

ISSN 2684-7280 (online)

Halaman 137-146

available online at http://jom.fti.budiluhur.ac.id/index.php/IDEALIS/index
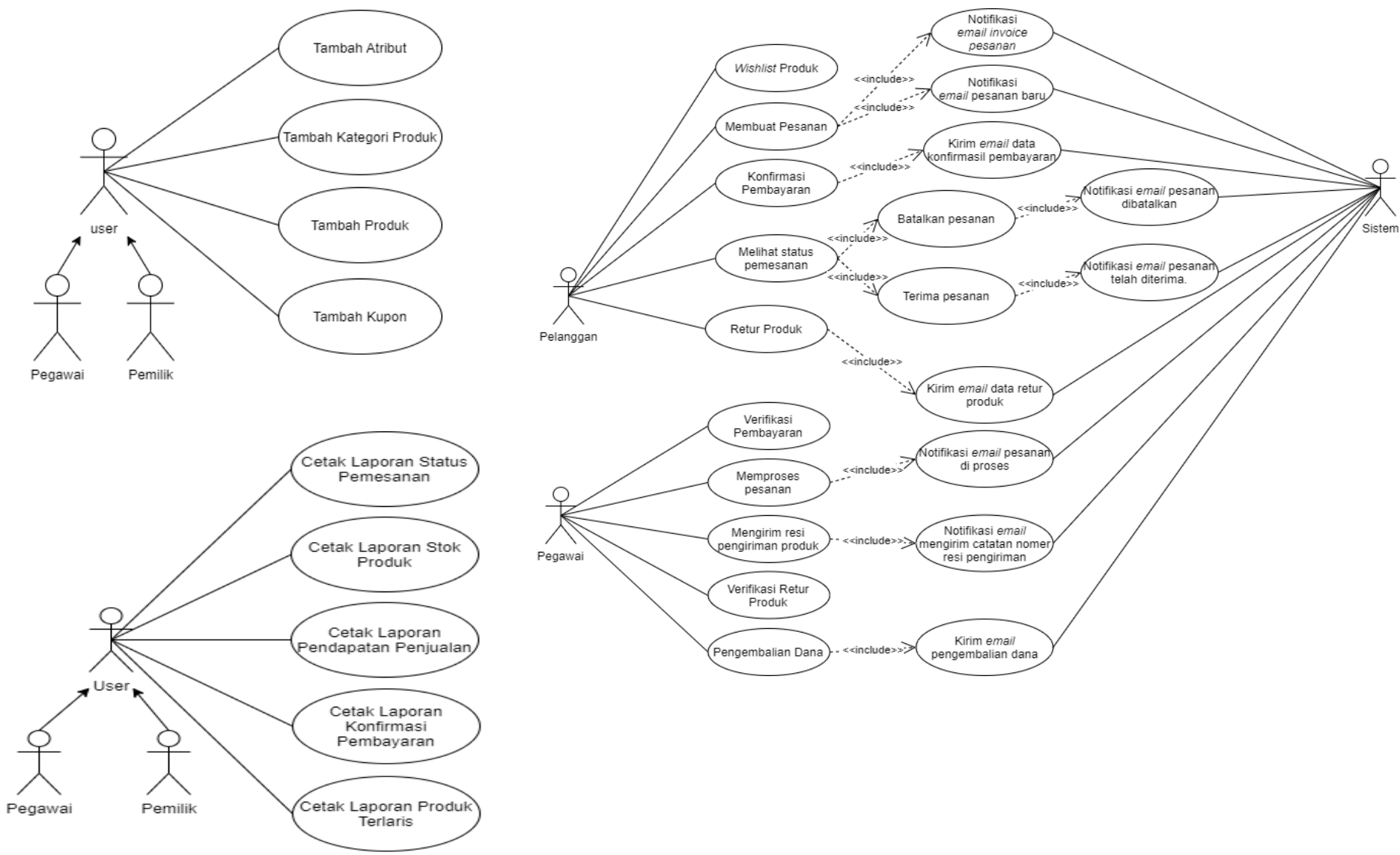

Gambar 5. Use Case Diagram Indah Jaya Sport

\subsection{Rancangan Layar}

Rancangan layar adalah prototipe dari desain tampilan halaman web awal, sering disebut sebagai antarmuka pengguna atau UI (user interface) [9].

a. Rancangan layar beranda

Rancangan layar beranda adalah halaman awal saat pelanggan membuka website indahjayasport.com, pada halaman ini pelanggan bisa melakukan berbagai aktivitas dan fitur yang terdapat didalamnya. Rancangan layar beranda dapat dilihat pada Gambar 6 :

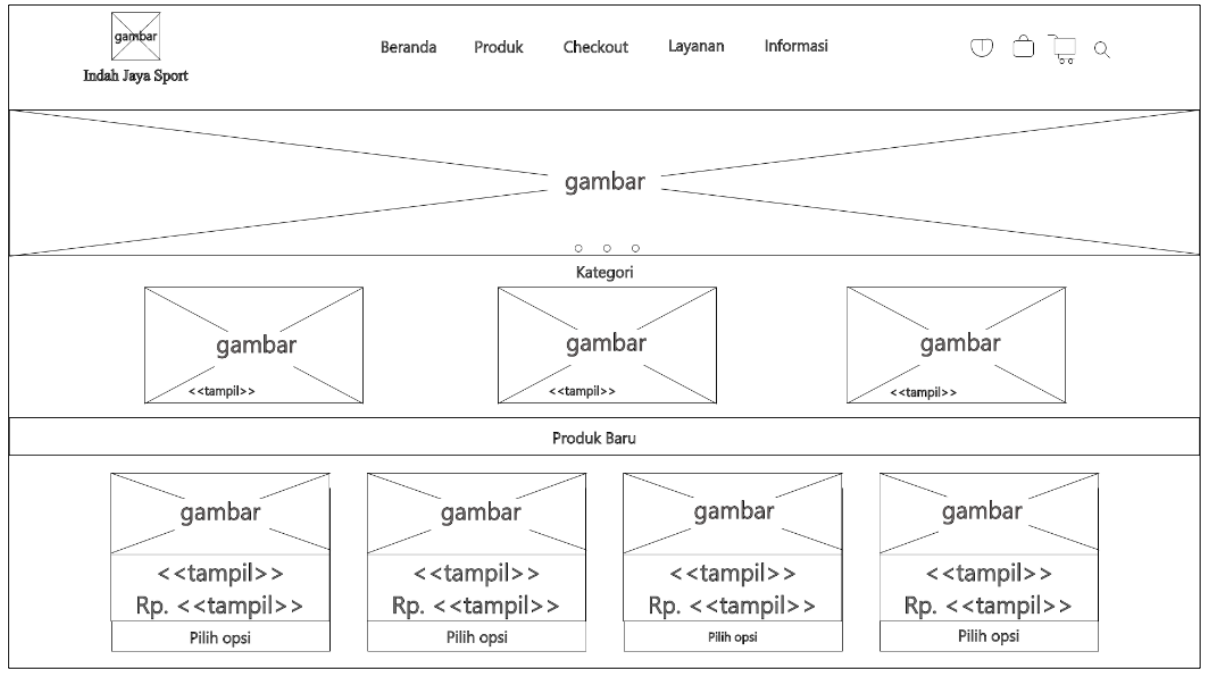

Gambar 6. Rancangan Layar Beranda Indah Jaya Sport 


\section{Halaman 137-146}

available online at http://jom.fti.budiluhur.ac.id/index.php/IDEALIS/index

\section{b. Rancangan layar checkout}

Rancangan layer checkout merupakan tampilan ketika pelanggan telah memilih produk dan telah memasukkannya ke dalam cart (keranjang), rancangan layar checkout ini menampilkan input text agar pelanggan dapat memasukkan alamat pengirimannya. Rancangan layar checkout bisa dilihat pada Gambar 7 :

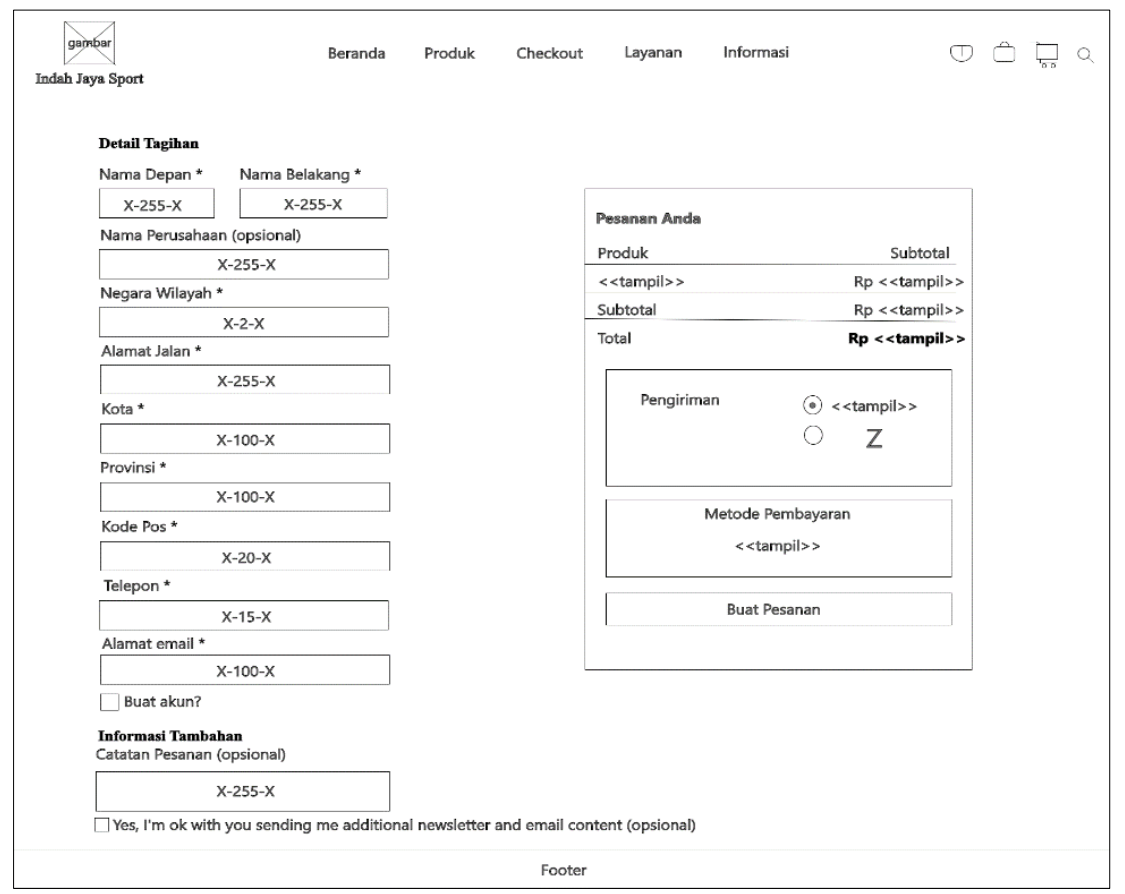

Gambar 7. Rancangan Layar Checkout Indah Jaya Sport

\section{c. Rancangan layar konfirmasi pembayaran}

Rancangan layar konfirmasi pembayaran toko Indah Jaya Sport mendeskripsikan ketika pelanggan selesai melakukan pemesanan dan melakukan pembayaran produk yang dipesan lalu mengkonfirmasi pembayaran tersebut pada halaman konfirmasi pembayaran. Rancangan layar konfirmasi pembayaran dapat dilihat pada Gambar 8 :

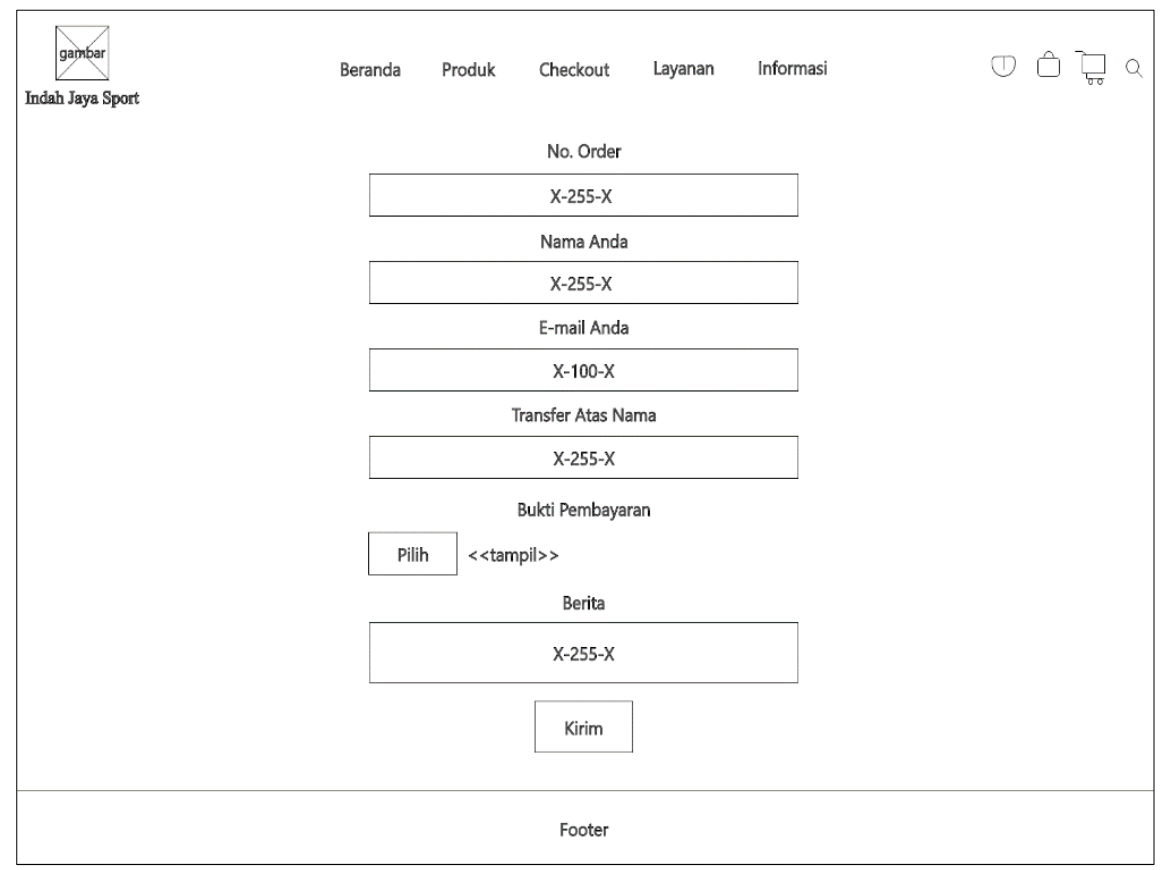

Gambar 8. Rancangan Layar Konfirmasi Pembayaran Indah Jaya Sport 


\section{Halaman 137-146}

available online at http://jom.fti.budiluhur.ac.id/index.php/IDEALIS/index

\section{d. Rancangan layar retur produk}

Rancangan layar retur produk menjelaskan pelanggan yang ingin melakukan retur atau penukaran terhadap produk yang telah di pesan karena suatu alasan, rancangan layar retur produk ini berisi input text agar pelanggan dan pihak Indah Jaya sport dapat melakukan verifikasi terhadap produk yang telah dipesan pelanggan. Rancangan layar retur produk dapat dilihat pada Gambar 9:

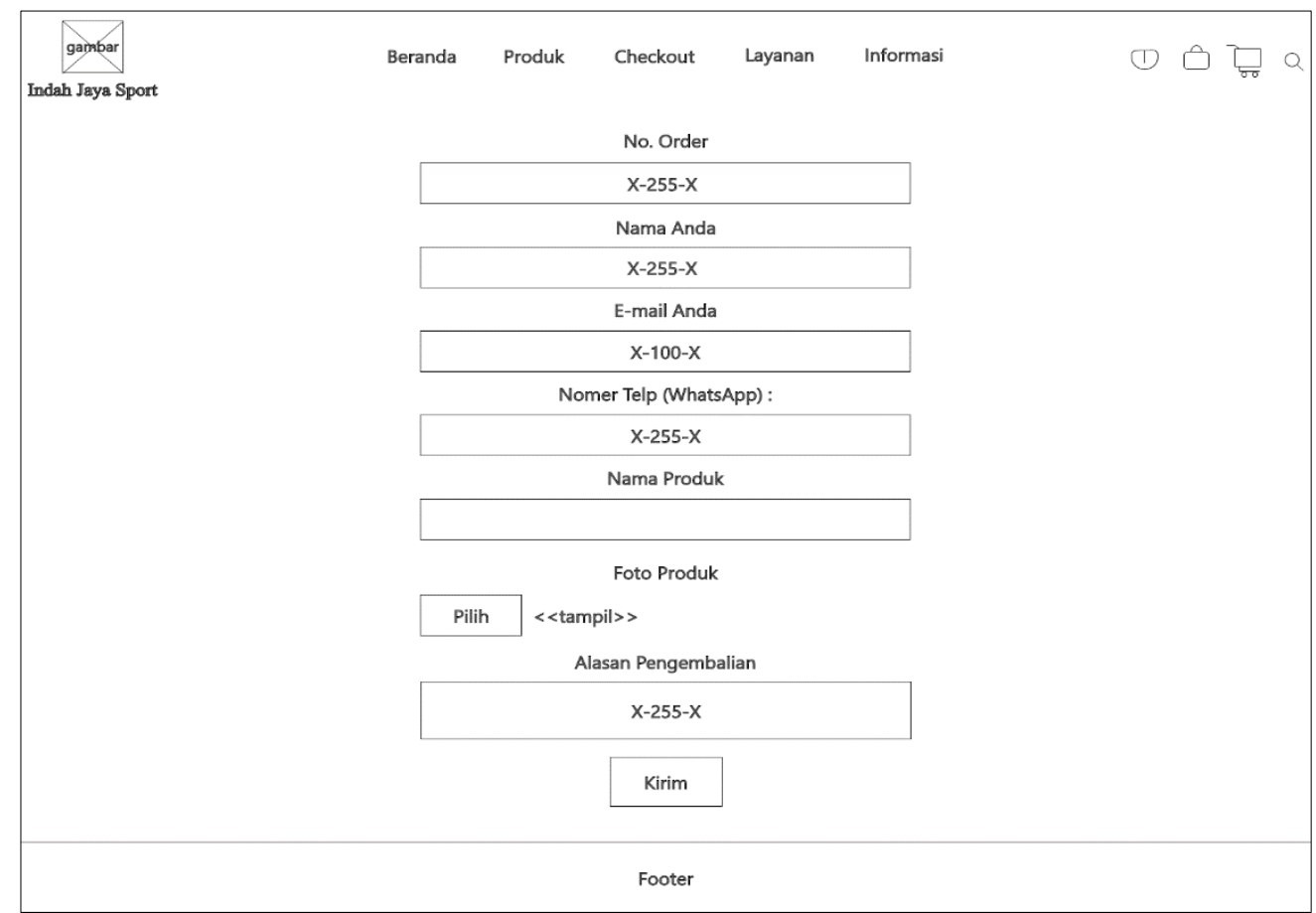

Gambar 9. Rancangan Layar Retur Produk Indah Jaya Sport

\subsection{Strategi Search Engine Optimization (SEO)}

Search Engine Optimization (SEO) adalah cara untuk memaksimalkan website agar dikenal oleh mesin pencari dan dibaca lebih lanjut. Teknik SEO dilakukan melalui proses yang sistematis, artinya teknik SEO wajib mengikuti peraturan yang berlaku untuk mesin pencari tertentu sebagai rujukan [3]. Berikut ini adalah langkahlangkah untuk mengoptimasi SEO dengan menggunakan tools Yoast SEO pada website toko Indah Jaya Sport :

a. Membuat kata kunci penelusuran yang berkaitan dengan produk dan membuat judul SEO, slug, serta deskripsi meta agar mudah ditemukan saat pelanggan mencari produk yang telah dilakukan optimasi SEO. Kata kunci, judul SEO, slug, dan deskripsi meta salah satu produk pada toko Indah Jaya Sport dapat dilihat pada Gambar 10:
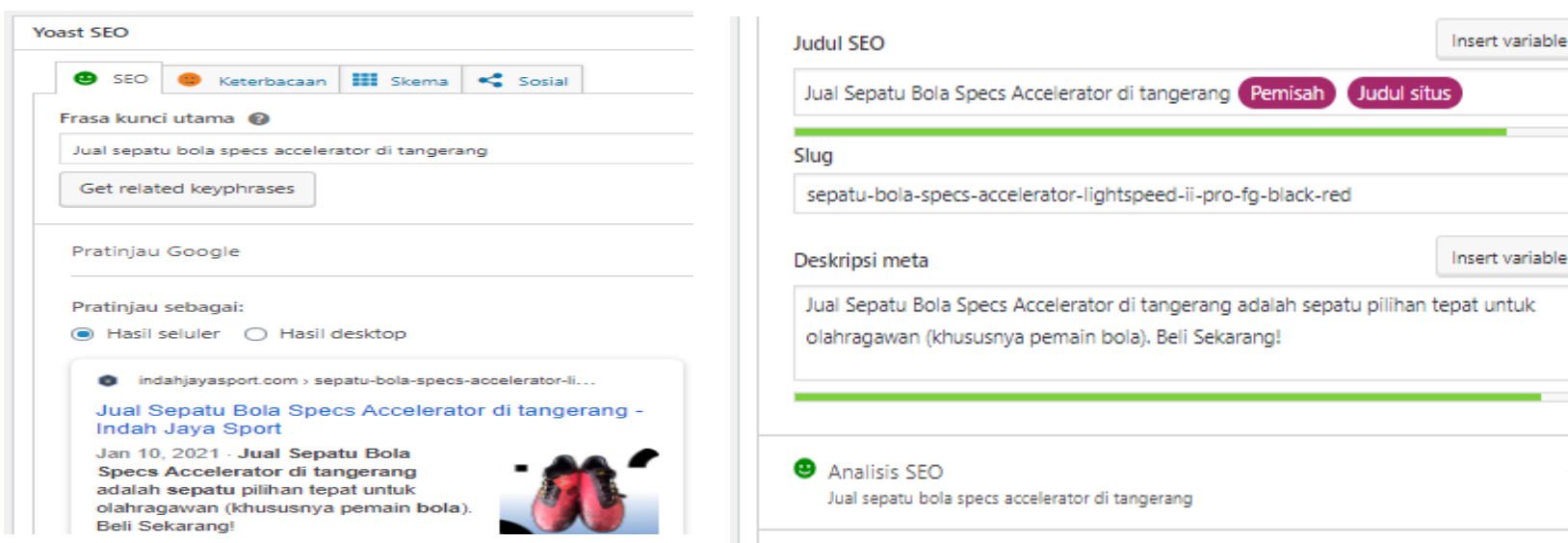

Gambar 10. Kata Kunci Penelusuran, Judul SEO, Slug, dan Deskripsi Meta 
b. Membuat teks alt berkaitan dengan kata kunci penelusuran agar kata kunci semakin mudah saat ditelusuri. Teks alt pada gambar produk dapat dilihat pada Gambar 11 :

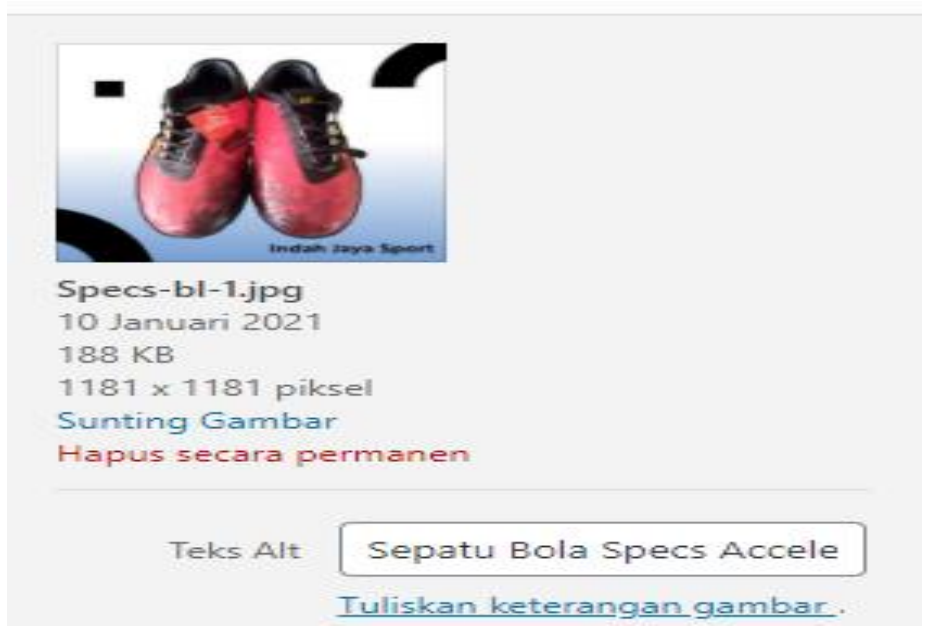

Gambar 11. Teks Alt pada Gambar Produk

c. Hasil penelusuran yang didapatkan ketika telah melakukan optimasi SEO. Hasil penelusuran tersebut didapatkan pada tanggal 5 Januari dan dapat dilihat pada Gambar 12 :

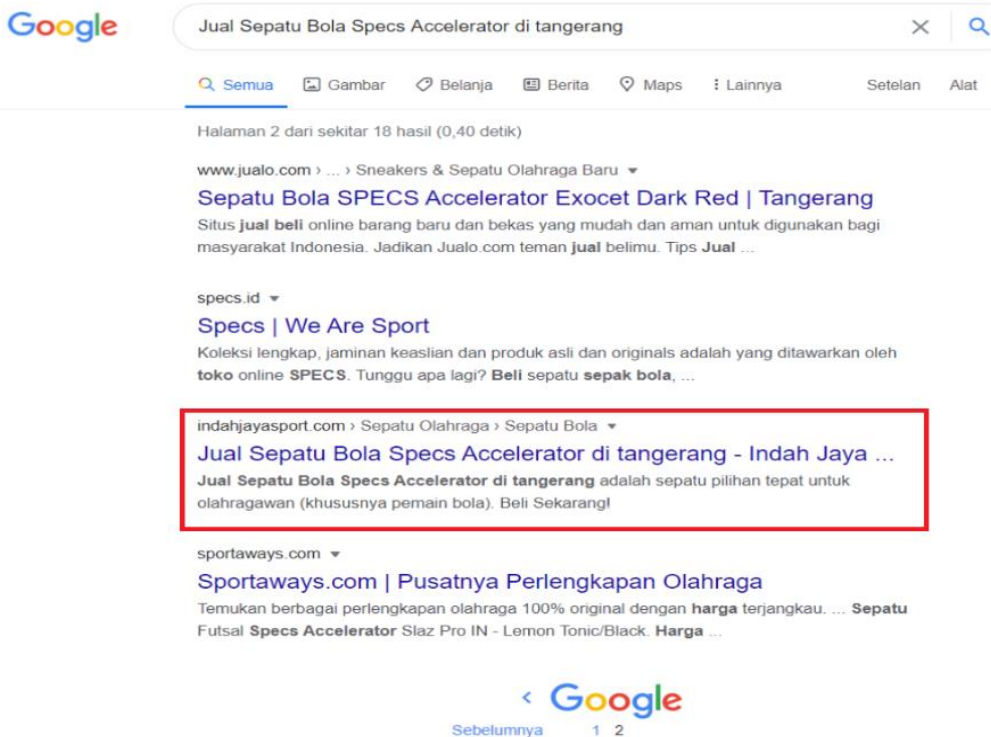

Gambar 12. Hasil Penelusuran pada Google

\subsection{Strategi Pemasaran}

Strategi pemasaran adalah memilih dan menganalisis target pasar yang menggambarkan sekelompok orang yang ingin dijangkau oleh perusahaan dan membuat suatu bauran pemasaran yang tepat pada target pasar tersebut [10]. Strategi pemasaran yang akan digunakan toko indah Jaya Sport adalah dengan menggunakan website agar dapat meningkatkan pendapatan penjualan, dengan cara meningkatkan kualitas konten di dalam website dan rajin mempublish produk baru agar pengunjung website percaya bahwasanya website ini memang benar-benar aktif. Website Indah Jaya Sport yaitu : https://indahjayasport.com serta menggunakan media sosial Facebook dan Instagram agar dapat menginformasikan produk kepada masayarakat luas. Media sosial Indah Jaya Sport yaitu :

a. Facebook : https://facebook.com/indahjayasport1

b. Instagram : https://instagram.com/indahjayasport 


\section{KESIMPULAN}

Kesimpulan dari implementasi e-commerce menggunakan content management system (cms) untuk memperluas pemasaran pada toko Indah Jaya Sport yaitu dengan adanya website e-commerce ini, toko Indah Jaya Sport dapat memiliki sarana untuk melakukan promosi serta sarana untuk penyampaian informasi dengan menggunakan fitur Search Engine Optimization (SEO), dan website Indah Jaya Sport (https://indahjayasport.com) dapat meperluas jangkauan pasar kepada pelanggan khususnya untuk diluar daerah Tangerang serta dengan toko online (e-commerce) yang fleksibel, pemilik dapat mengetahui cara meningkatkan penjualan karena dapat berjualan secara efektif dengan menggunakan toko online yang dapat membuat pelanggan membeli dimana saja tanpa terhalang tempat, (selama masih ada internet) dan menjalankan toko fisik secara bersamaan dengan tujuan meningkatkan transaksi yang diperoleh toko Indah Jaya Sport.

\section{DAFTAR PUSTAKA}

[1] F. Ramadhan and L. Fajarita, "Implementasi Rancangan E-Commerce pada Surya Timur Collection dengan Metode Business Model Canvas (BMC) Berbasis Content Management System (CMS)," Jurnal IDEALIS, vol. 3, no. 1, pp. 251-259, 2020.

[2] E. Yulianto and A. Mauluddin, "Penerapan E-Commerce Berbasis Business To Customer (B2C) pada Industri Garment," In Search, vol. 18, no. 01, pp. 124-136, 2019.

[3] A. Sofyan, E. Ferdianto, R. Rahmawati, and R. K. Aldi, "Pengaruh Search Engine Optimization (SEO) dan Riset Kata Kunci Terhadap Pendapatan Toko Online," Indonusa Conf. Technol. Soc. Sci., vol. 1, no. 1, pp. 351-356, 2019.

[4] A. Widyanto and H. Patrie, "Implementasi Penjualan Bebasis E-Commerce Pada Toko Synergie Motor," Jurnal IDEALIS, vol. 3, no. 1, pp. 92-100, 2020.

[5] T. dwi Alperdo and G. Gata, "Implementasi E-Commerce Menggunakan Business Model Canvas dan Ifml pada Distro Mr Bro," Jurnal IDEALIS, vol. 2, no. 6, pp. 369-376, 2019

[6] T. A. Putra and Y. Santoso, "Implementasi E-Commerce Sebagai Media Penjualan Online Pada Toko Tatashops," Jurnal IDEALIS, vol. 2, no. 6, pp. 1-7, 2019.

[7] L. A. Kurniawan, "Wordpress Dalam Perkuliahan Kepenulisan di Program Studi Pendidikan Bahasa dan Sastra Indonesia," Sasindo J. Pendidik. Bhs. dan Sastra Indonesia, vol. 7, no. 1, pp. 1-10, 2019.

[8] D. W. T. Putra and R. Andriani, "Unified Modelling Language ( UML ) dalam Perancangan Sistem Informasi Permohonan Pembayaran Restitusi SPPD,” J. TEKNOIF, vol. 7, no. 1, pp. 32-39, 2019.

[9] E. Revsie Akbar and H. Irawan, "Analisis dan Implementasi E-Commerce Menggunakan CMS Wordpress pada Queenita Classic," Jurnal IDEALIS, vol. 4, no. 1, pp. 107-116, 2021.

[10] E. D. Wawolumaya, D. L. Tampi, and J. J. Rogahang, “Analisis Strategi Pemasaran Dalam Upaya Meningkatkan Volume Penjualan pada Rose Collection Manado," Productivity, vol. 1, no. 2, pp. 134-141, 2020. 